\title{
Description of the Response of a New Multi-Parametric Brain Sensor to Physiological and Pathophysiological Challenges in the Cortex of Juvenile Pigs
}

\author{
Yeni Bir Multi Parametrik Beyin Sensörünün Juvenil Domuzlarn \\ Korteksinde Fizyolojik ve Patofizyolojik Değişikliklere Cevabının Tanım
}

\author{
Anna LEIDORF ${ }^{1^{*}}$, Marius M. MADER ${ }^{1^{*}}$, Andreas HECKER ${ }^{1^{*}}$, Axel HEIMANN ${ }^{1}$, Beat ALESSANDRI ${ }^{1}$, \\ Petra S M MAYR ${ }^{1}$, Oliver KEMPSKI ${ }^{1}$, Gabriele WÖBKER ${ }^{2}$ \\ ${ }^{1}$ University Medical Center of the Johannes Gutenberg University, Institut for Neurosurgical Pathophysiology, Langenbeckstr 1, \\ Mainz, Germany \\ ${ }^{2}$ HELIOS Clinics, Department of Intensive Care Medicine, Wuppertal-Bamen, Germany \\ ${ }^{*}$ Equally contributing authors.
}

Corresponding Author: Beat ALESSANDRI / E-mail: alessand@mail.uni-mainz.de, beat.alessandri@unimedizin-mainz.de

\begin{abstract}
AIM: Monitoring of intracranial pressure (ICP), local cerebral blood flow (CBF) and oxygen is part of modern intensive critical care medicine. Preclinical evaluation of newly developed catheters that should monitor several parameters simultaneously is reported poorly in the literature. The goal of our study was (1) to evaluate a new multi-parametric sensor in brain tissue and (2) to establish a testing protocol using pathophysiological challenges that target measured parameters of the sensor and autoregulatory boundaries and could be used as preclinical standard protocol in future studies.
\end{abstract}

MATERIAL and METHODS: We describe data from 12 new multi-parametric brain sensors (MPBS) that were implanted into 3 porcine brains and combined measurement of brain tissue oxygenation $\left(\mathrm{ptiO}_{2}\right), \mathrm{ICP}, \mathrm{CBF}$ and brain temperature for the first time. Pigs were treated with a period of hyperoxygenation, hypercapnia, hypoxia, dobutamine, and norepinephrine.

RESULTS: None of the 12 MPBS failed. Our testing protocol induced standardized pathophysiological changes that were picked up by the new MPBS as significant alterations in brain $\mathrm{ptiO}_{2^{\prime}} \mathrm{ICP}$ and CBF. The magnitude of changes was $>20 \%$ in most tested MPBS.

CONCLUSION: An experimental protocol with pre-defined end-points for $\mathrm{O}_{2^{\prime}} \mathrm{CO}_{2^{\prime}}$ blood pressure and cardiac output should be standardized and reported if new sensors for multi-parametric brain monitoring are evaluated. The use of several sensors per brain of only a few animals is sufficient to determine functionality of new sensors in vivo as basis for a larger study with reference sensors and brain injury.

KEYWORDS: ICP, Multi-parametric neuromonitoring, Hypercapnia, Hyperoxygenation, Hypoxia, Pig

Öz

AMAÇ: İntrakraniyal basınç (IKB), yerel serebral kan akışı (SKA) ve oksijenin izlenmesi modern yoğun bakım tıbbının bir parçasıdır. Literatürde aynı anda birkaç parametreyi izleyecek yeni geliştirilmiş kateterlerin preklinik değerlendirmesi hakkında çok az bilgi vardır. Çalışmamızın amacı, (1) beyin dokusunda yeni bir multi-parametrik sensörü değerlendirmek ve (2) sensör ve otoregülasyon sınırlarını hedefleyen patofizyolojik değişiklikler kullanan ve gelecekteki çalışmalarda preklinik standart bir protokol olarak kullanılabilecek bir test protokolü belirlemekti.

YÖNTEM ve GEREÇLER: Üç domuz beynine implante edilen 12 yeni multi-parametrik beyin sensörü (MPBS) ve ilk kez beyin dokusu oksijenizasyonu ( $\mathrm{ptiO}_{2}$ ), İKB, SKA ve beyin sıcaklığının kombine ölçümüyle ilgili veriler sunuyoruz. Domuzlar hiperoksijenasyon, hiperkapni, hipoksi, dobutamin ve norepinefrin dönemlerinden geçti.

BULGULAR: 12 MPBS'den hiçbiri başarısız olmadı. Test protokolümüz yeni MPBS tarafından beyin ptiO2, ICP ve SAK değerlerinde önemli değişiklikler olarak saptanan standardize patofizyolojik değişikliklere neden oldu. Değişikliklerin büyüklüğü çoğu test edilen MPBS ile \%20 civarındaydı.

SONUÇ: $\mathrm{O}_{2^{\prime}} \mathrm{CO}_{2^{\prime}}$ kan basıncı ve kardiyak çıktı için önceden tanımlanmış son noktaları olan deneysel bir protokol standardize edilmeli ve multi parametrik beyin izleme için yeni sensörler değerlendirilirse bunlarla sonuçlar bildirilmelidir. Sadece birkaç hayvanda her beyinde birkaç sensör kullanılması yeni sensörlerin in vivo olarak referans sensörler ve beyin hasarıyla daha büyük bir çalışmanın temeli olarak kullanılmasına karar vermek açısından yeterlidir.

ANAHTAR SÖZCÜKLER: İB, Multi parametrik nöromonitörizasyon, Hiperkapni, Hiperoksijenasyon, Hipoksi, Domuz 


\section{INTRODUCTION}

Increased intracranial pressure (ICP), reduced cerebral perfusion pressure (CPP) and local changes of cerebral blood flow (CBF), oxygen and substrate delivery as well as release of neurotoxic mediators mark the pathophysiology of severe traumatic brain injury (TBI) and subarachnoid hemorrhage (SAH) (12). Advanced neuromonitoring in the intensive care unit includes measurements of continuous ICP, brain tissue oxygenation $\left(\mathrm{ptiO}_{2}\right.$ ) and extracellular energy metabolites by microdialysis and intermittent measurements of CBF by CT-scan. Gathered information can be used for maintaining adequate ICP, CPP and brain oxygenation. Experimental and clinical studies have shown the benefits of such multiparametric neuromonitoring for patients following severe TBI or SAH (3). Until recently, implanted catheters measured only a single modality, e.g. oxygen tension by Licox ${ }^{\circledR}$ catheters, and two or more catheters had to be implanted into brain tissue in order to collect several parameters simultaneously. This makes handling of multi-parametric neuromonitoring work intensive and a combination of sensors in a single catheter is desirable. A first step was the integration of the separately implanted temperature probe from Licox into a new LicoxPMO catheter (Integra LifeSciences, USA) combining tissue oxygen measurement by a Clark-type electrode with temperature measurement by a thermistor element (35). A further step was the integration of a pressure sensor for ICP, luminophores (silicone-soluble fluorescence dye complex) for oxygen and a thermocouple for temperature measurement in a single catheter by Raumedic (Neurovent-PTO). First experimental and clinical comparison of the standard method (Licox CC1.SB; Clark-type electrode) with Neurovent-PTO (luminophores) showed a good correlation for oxygen $(6,27)$. Thus, combining various sensors in one catheter with an acceptable size (diameter eg. 5F) and performance is feasible. However, a literature review shows that there seems to be no consensus about a standardized protocol how to test new multi-parametric sensors.

In collaboration with Oxford Optronix Ltd. (Abingdon, UK) and Millar Instruments (Houston, USA) we now extended the range of parameters by merging a Laser-Doppler and sensors for ICP, $\mathrm{ptiO}_{2}$ and temperature into one catheter. A trial run with a first sensor design already called for modifications, although this first series of sensors reacted well in vitro. In order to test whether or not the newly designed multi-parameter catheter works in brain tissue we implanted a total of 12 catheters (4/ animal) into the porcine cortex and provoked reactions of each sensor unit by physiological, pathophysiological and pharmacological manipulations. The results should provide evidence (1) for the functionality of the MPBS in vivo and (2) for the importance of a standardize protocol to evaluate new multi-parametric sensors. Data of this small scale study should be the basis for a large in vivo experimental series using the new sensors in combination with standard reference sensors and an injury model.

\section{MATERIAL and METHODS}

Multi-parameter brain sensor (MPBS, Oxford Optronix Ltd., Abingdon, UK)

As depicted in Figure 1 the new catheter consists of four units measuring oxygen tension, temperature, pressure and blood flow via laser Doppler flowmetry simultaneously. The units are arranged along a steel shaft (length: $14.5 \mathrm{~mm}$; diameter: max. $1.97 \mathrm{~mm}$, tip $0.97 \mathrm{~mm}$ ) and the implemented measuring technology is described below:

\section{ptiO $_{2}$ (and temperature) Measuring Principle}

The $\mathrm{ptiO}_{2}$ sensing part of the MPBS probe is based on fibreoptic light guides and provides a continuous measure of oxygen partial pressure for real-time monitoring of temporal oxygen changes in the cerebral tissue.

A fluorophore is permanently immobilised and enclosed within a silicone matrix under the metal caging. The lifetime of fluorescence is inversely proportional to the concentration of dissolved oxygen and is interpreted to provide an absolute value for $\mathrm{ptiO}_{2}$ in $\mathrm{mmHg}$ or $\mathrm{kPa}$.

Fluorescence lifetime is longest at low $\mathrm{ptiO}_{2}$, making the sensor most sensitive in the physiological range $0-60 \mathrm{mmHg}$. The measurement is based on fluorescence lifetime rather than fluorescent intensity.

Compensation for the effects of temperature is required since fluorescent lifetimes are affected by changes in temperature. This is done by a fully integrated thermocouple in the MPBS sensor, allowing continuous monitoring of temperature as well as automatic (background) temperature correction for the $\mathrm{ptiO}_{2}$ values.

The probe is pre-calibrated by the manufacturer and requires no further intervention. As a standard procedure for evaluation of new probes we placed the catheters in distilled water bubbled with air as well as in a solution with no free oxygen $(0.26 \mathrm{~g}$ sodium tetraborat, $1.63 \mathrm{~g}$ sodium sulfite, $1 \mathrm{~L}$ dest. water).

\section{Laser Doppler Flowmetry Principle}

Laser Doppler flowmetry is an established technique for the real-time measurement of microvascular red blood cell (erythrocyte) perfusion in tissue (e.g. 7).

The MPBS probe has two integrated optical fibre light guides for measuring microvascular blood perfusion. Laser light goes through one fibre and is scattered within the tissue. Another optical fibre collects the backscattered light from the tissue and returns it to the monitor.

Most of the scattered light is from tissue that is not moving but a small percentage of the returned light is scattered by moving red blood cells. The light returned to the monitor undergoes signal processing whereby the emitted and returned signals are compared to extract the Doppler shift related to moving red blood cells. 
The obtained microvascular blood perfusion signal is the product of mean red blood cell velocity and mean red blood cell concentration in the volume of tissue under illumination from the probe. It is expressed in relative units called Blood Perfusion Units (BPU). These relative BPU are defined over a scale by the manufacturer using a carefully controlled motility standard comprising a suspension of latex spheres undergoing Brownian motion. Nevertheless, a 'biological zero' was established after cardiac arrest following 7.45\% potassium chloride ( $\mathrm{KCl}$, B.Braun, Melsungen, Germany) injection.

\section{ICP (Intracranial Pressure)}

ICP is an established and accepted method for real-time pressure measurement of brain tissue and fluids alike. The MPBS probe uses Millar solid-state Micro-Electro-Mechanical Systems (MEMS) sensor technology for its pressure measurement technology. The MPBS catheter assembly houses micro-miniature piezo-resistive $1 / 2$ bridge ( 2 active) sensors that are completed in a Wheatstone bridge. This bridge forms a pressure transducer that produces voltage being proportional to the pressure applied to the pressure sensor surface. The specific monitoring equipment filters, amplifies and displays the particular pressure waveforms in real-time.

This MEMS technology allows for a micro-miniature sensor to be used at a high frequency response capability. This microminiature sensor also allows room for the other optical fibers required for the other sensors already mentioned within the MPBS lumen. Since solid-state technology is used vs. fluid-filled the pressure is measured at the point source and not through a water filled tube. Also the pressure sensing capability is such that very small pressure changes can be detected. Finally due to the solid-state technology being used, high frequency artefacts of the pressure waveform can be analysed if required.

\section{1- Animals and surgical procedures}

All experiments were approved by the ethical committee for Animal Use and Care and performed according to national guidelines for animal experiments. Three (3) juvenile male pigs at the age of 3-4 months (German breed; $29-32 \mathrm{~kg}$ ) were used. Initial medication consisted of i.m injection of ketamine (15 mg/kg), azaperone (3 mg/kg; Sanochemia Pharmazeutika, Neufeld, Austria) and atropine (1 mg, B.Braun AG, Melsungen, Germany). After cannulation of an ear vein $10 \mathrm{ml}$ thiopental (25 mg/ml; Trapanal, Nycomed, Konstanz, Germany; \#PZN1037554) was injected. Thereafter, thiopental was infused continuously at a rate of $10-15 \mathrm{mg} / \mathrm{kg}$ bw/h. Piritramid (1 mg/ $\mathrm{ml}$; Dipidolor, Janssen-Cilag Pharmaceuticals $\mathrm{GmbH}$, Neuss, Germany, \#PZN-1312724) was used for analgesia at a rate of $0.2-0.3 \mathrm{mg} / \mathrm{kg} \mathrm{bw} / \mathrm{h}$. All animals were intubated (SuperSafety-Clear, i.d/o.d. 6.0/5.5 mm, Teleflex, Rüsch, Germany) and mechanically ventilated (900B; Siemens-Elema $A B$, Erlangen, Germany). $\mathrm{FiO}_{2}$ and et $\mathrm{CO}_{2}$ were monitored throughout the experiment (Capnomag Ultima; Datex Engstrom Division, UK). Pigs were placed on a heating pad (Homeothermic Blanket
Systems, Harvard Apparatus, Hugo Sachs Elektronik, MarchHugstetten, Germany) and body temperature was kept at $38.5 \pm 1.5^{\circ} \mathrm{C}$. No muscle relaxation was employed.

\section{Surgical Preparation}

The femoral artery and vein were cannulated for blood pressure monitoring, withdrawal of blood for blood gas analysis and volume therapy. The jugular vein was cannulated for hemodynamic and cardiac parameters such as the cardiac index (Cl), systemic vascular resistance (SVR) and systemic vascular volume (SVV) by PiccoPlus (PULSION Medical Systems AG, München, Germany). Animals were fixed in a stereotaxic frame and a skin incision was made to expose the skull. The periosteum was carefully removed and the bone disinfected. Burr holes for probe insertion were drilled over the left and right cortex (two burr holes/hemisphere, MicroTron 60, Aesculap, Germany). The dura mater was perforated using a sterile needle (G20) to allow probe insertion to an initial depth of $15 \mathrm{~mm}$. After placement each probe was fixed in place using bone wax (Johnson\&Johnson Medical, Norderstedt, Germany).

\section{2-Study protocol}

The goal of the study protocol was to induce an increase, decrease or no change of measured values from baseline in uninjured tissue, i.e. to challenge the four different parameters of MPBS (Figure 2). Therefore, brain $\mathrm{ptiO}_{2}$ was manipulated by hyperoxygenation (arterial $\mathrm{pO}_{2}>400 \mathrm{mmHg}$ ) and hypoxia (arterial $\mathrm{pO}_{2}<40 \mathrm{mmHg}$ ). We achieved hyperoxia by increasing $\mathrm{FiO}_{2}$ and hypoxia by ventilation with an air $/ \mathrm{N}_{2}$ mixture. Changes of ICP and CBF were induced by hypercapnia $\left(\mathrm{paCO}_{2}>70 \mathrm{mmHg}\right.$ ) and also by hypoxia. Hypercapnia was induced by the method of apnoeic oxygenation. During a 15-min episode, ventilation was discontinued but lungs were flooded with oxygen by means of an inserted tube. Thus,

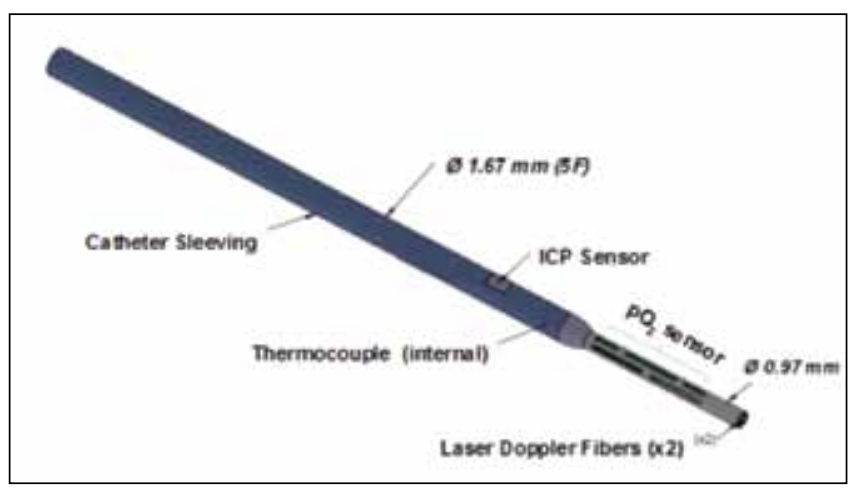

Figure 1: Schematic drawing of the multi-parameter brain sensor (MPBS; Oxford Optronix Ltd., Abingdon, UK). The catheter consists of 4 different sensor modules that measure oxygen, pressure, blood flow and temperature. The catheter shaft with 4 sensors has a diameter of $5 F(=1.67 \mathrm{~mm})$. The Neurovent-PTO (Raumedic AG, Helmbrechts, Germany) with 3 sensor modules (pressuretemperature-oxygen) and the Licox-PMO (Integra, Burlington, MA, USA) with 2 sensor modules (temperature-oxygen) have dimensions of $1.67 \mathrm{~mm}$ and $0.8 \mathrm{~mm}$, respectively. 


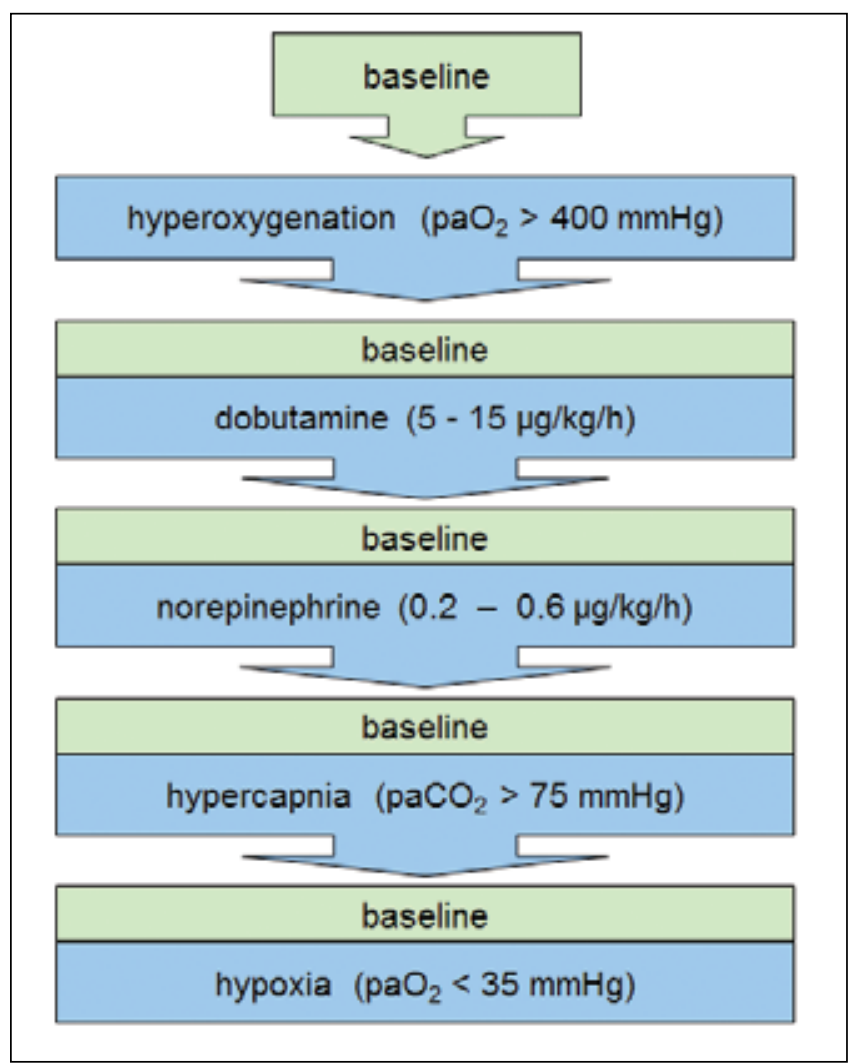

Figure 2: Schematic drawing of the experimental protocol for the evaluation of multi-parameter sensors. The protocol starts with an equilibration time of 60-120 min followed by a 15-min baseline. Subsequently a series of physiological and pathophysiological manipulation (10-45 $\mathrm{min}$ ) are performed in order to challenge sensors differently. Each challenge is followed by a normalization period of at least 15 min or until stable values are reached. Introduction of a brain injury by e.g. focal ischemia or controlled cortical impact could be used to damage autoregulatory mechanisms and would allow to detect effects of dobutamine and norepinephrine. Our first tests on three pigs were performed without previous injury.

blood remained oxygenated but no effective $\mathrm{CO}_{2}$ exchange takes place anymore. Since thiopental already suppressed spontaneous breathing no additional medication for muscle relaxation was necessary. No specific manipulation was induced for temperature that should follow changes of CBF passively. No alteration of $\mathrm{ptiO}_{2^{\prime}} \mathrm{ICP}, \mathrm{CBF}$ and temperature was expected at intact autoregulation by manipulation of mean arterial blood pressure (MAP) by infusion of norepinephrine $(0.2 / 0.4 / 0.6 \mu \mathrm{g} / \mathrm{kg} / \mathrm{h}$; Arterenol, Sanofi-Aventis, \#PZN7800040) and cardiac output by dobutamine $(5,10,15 \mu \mathrm{g} /$ kg/h; Carinopharm GmbH, \#PZN-4344877).

Hyperoxygenation and hypercapnia lasted for $15 \mathrm{~min}$. Both pharmacological manipulations consisted of a continuous, stepwise increase of the infused concentration of norepinephrine or dobutamine. Each step also lasted for $15 \mathrm{~min}$. The hypoxic period lasted for a maximum of $10 \mathrm{~min}$ in order to enable recovery (Figure 2). Before the first and after each challenge a recovery period was inserted which lasted for $15 \mathrm{~min}$ or until stable values were reached again.

\section{Data Analysis}

Data were recorded at $1 \mathrm{~Hz}$ and plotted real-time using LabChart Software (ADInstruments). Data were transferred to Sigmaplot (Systat Ldt.) to display them as online recording and as mean 5 -min average $( \pm S D)$. A paired t-test was used to compare baseline values before each challenge with the 5,10 and 15-min time point of the particular challenge.

\section{RESULTS}

A total of 12 MPBS in three pigs were tested yielding a total of 180 datasets (dataset $=$ baseline +15 -min challenge). As described in Table I some datasets were rejected due to malfunctioning sensors, incomplete sampling or accidental MPBS manipulation. Figure $3 \mathrm{~A}$ and $4 \mathrm{~A}-\mathrm{C}$ show online recordings of the same MPBS reacting to an episode of hyperoxygenation, hypercapnia, hypoxia and treatment with dobutamine and norepinephrine.

\section{Brain Tissue Oxygen}

Although $\mathrm{ptiO}_{2}$ started at different baseline levels (range: $1.6-49.2 \mathrm{mmHg}$ ) all MPBS reacted to hyperoxygenation and hypoxia (Table I). Only subtle effects were seen during dobutamine and norepinephrine infusion. Statistical comparison between baseline and the 5-, 10- and 15-min time-point within challenges indicated that a significant number of $\mathrm{O}_{2}$-sensing modules picked-up even small changes during dobutamine infusion (Figure 3B). Mean $\mathrm{ptiO}_{2}$ at beginning of the protocol was $17.4 \pm 18.3 \mathrm{mmHg}$ and declined only slightly to $14.4 \pm 11.0 \mathrm{mmHg}$ just before the hypoxic episode. The highest brain tissue oxygen levels were reached in all cases at the end of increased $\mathrm{FiO}_{2}$ with $31.4 \pm 31.6 \mathrm{mmHg}$ (blood oxygen $528 \pm 49 \mathrm{mmHg}$ ). All sensors showed a decline of ptiO $\mathrm{O}_{2}$ to a minimum of $2.2 \pm 2.2 \mathrm{mmHg}$ at the end of hypoxia (blood oxygen $25 \pm 4 \mathrm{mmHg}$ ). Flooding of lungs with oxygen during apnoeic oxygenation could not keep blood oxygen at a constant level. Therefore, $\mathrm{ptiO}_{2}$ is not shown in Figure 3 and Table I in order not to provoke false interpretation of $\mathrm{ptiO}_{2}$ changes due to increased $\mathrm{paCO}_{2}$.

\section{Intracranial Pressure}

Baseline ICP ranged from 5.1 to $16.9 \mathrm{mmHg}$ for the 12 MPBS in the three pigs at the beginning of the experimental protocol (mean: $10.4 \pm 3.0 \mathrm{mmHg}$ ). After each challenge ICP returned to baseline level and there was no permanent change of mean ICP until the end of the protocol $(12.2 \pm 11.2 \mathrm{mmHg}$; Figure $4 \mathrm{~A}, \mathrm{~B})$. ICP changes could be evoked by hypercapnia $\left(\mathrm{paCO}_{2}=104 \pm 2.6 \mathrm{mmHg}\right)$ and hypoxia. ICP rose to a maximum of $25.9 \pm 9.7 \mathrm{mmHg}$ and $20.3 \pm 10.3 \mathrm{mmHg}$ at the end of the hypercapnic and hypoxic episode, respectively. Similar to the $\mathrm{O}_{2}$-sensing module a significant number of the pressure modules picked-up even small changes during treatment with dobutamine and norepinephrine (Figure 4B). 
Table I: Number of Analyzed 15-Min Datasets Per Challenge (Hyperoxygenation, Hypercapnia, Hypoxia) and Per Parameter (ptiO ${ }_{2}$ ICP, CBF) Which Showed an Increase or Decrease of Measured Values. A Total of 108 Datasets were Analyzed of Which 27 had to be Rejected ${ }^{1}$. Changes are Categorized in Percent (\%) from Baseline.

\begin{tabular}{|c|c|c|c|c|c|c|c|c|}
\hline \multirow{2}{*}{ Challenge } & \multirow{2}{*}{ Parameter } & \multirow{2}{*}{$\begin{array}{l}\text { Analyzed } \\
\text { datasets }\end{array}$} & \multicolumn{3}{|c|}{ Reaction categories: decrease } & \multicolumn{3}{|c|}{ Reactin categories: increase } \\
\hline & & & $>-20 \%$ & -20 to $-10 \%$ & -10 to $0 \%$ & 0 to $10 \%$ & 10 to $20 \%$ & $>20 \%$ \\
\hline \multirow{3}{*}{ Hyperoxygenation } & $\mathrm{ptiO}_{2}$ & 10 & 0 & 0 & 0 & 0 & 0 & $10(100 \%)$ \\
\hline & $\mathrm{ICP}$ & 12 & 0 & 1 & 5 & 3 & 2 & 0 \\
\hline & $\mathrm{CBF}$ & 10 & 2 & 2 & $6(60 \%)$ & 0 & 0 & 0 \\
\hline \multirow{3}{*}{ Hypercapnia } & $\mathrm{ptiO}_{2}$ & 0 & $* *$ & $* *$ & $* *$ & $* *$ & & \\
\hline & $\mathrm{ICP}$ & 11 & 0 & 0 & 0 & 0 & 0 & $11(100 \%)$ \\
\hline & $\mathrm{CBF}$ & 9 & 0 & 2 & 0 & 0 & $3(33 \%)$ & 4 (44\%) \\
\hline \multirow{3}{*}{ Hypoxia } & $\mathrm{ptiO}_{2}$ & 9 & $9(100 \%)$ & 0 & 0 & 0 & 0 & 0 \\
\hline & $\mathrm{ICP}$ & 11 & 0 & 0 & 0 & 0 & 1 & 10 (91\%) \\
\hline & CBF & 9 & 1 & 3 & 0 & 0 & 2 & 3 \\
\hline
\end{tabular}

'Rejected datasets: 6 datasets due to 2 malfunctioning $\mathrm{O}_{2}$-sensors in the same pig; 6 datasets due to 2 malfunctioning CBF-sensors (no reaction to any challenge); 5 datasets due to accidental handling of a MPBS during hypercapnia that also affected values during hypoxia; 10 datasets for ptiO during hypercapnia due to unstable blood oxygen levels induced by apnoeic oxygenation**.

ptiO $_{2}=$ partial pressure of tissue oxygen; $\mathbf{I C P}=$ intracranial pressure; $\mathbf{C B F}=$ cerebral blood flow.

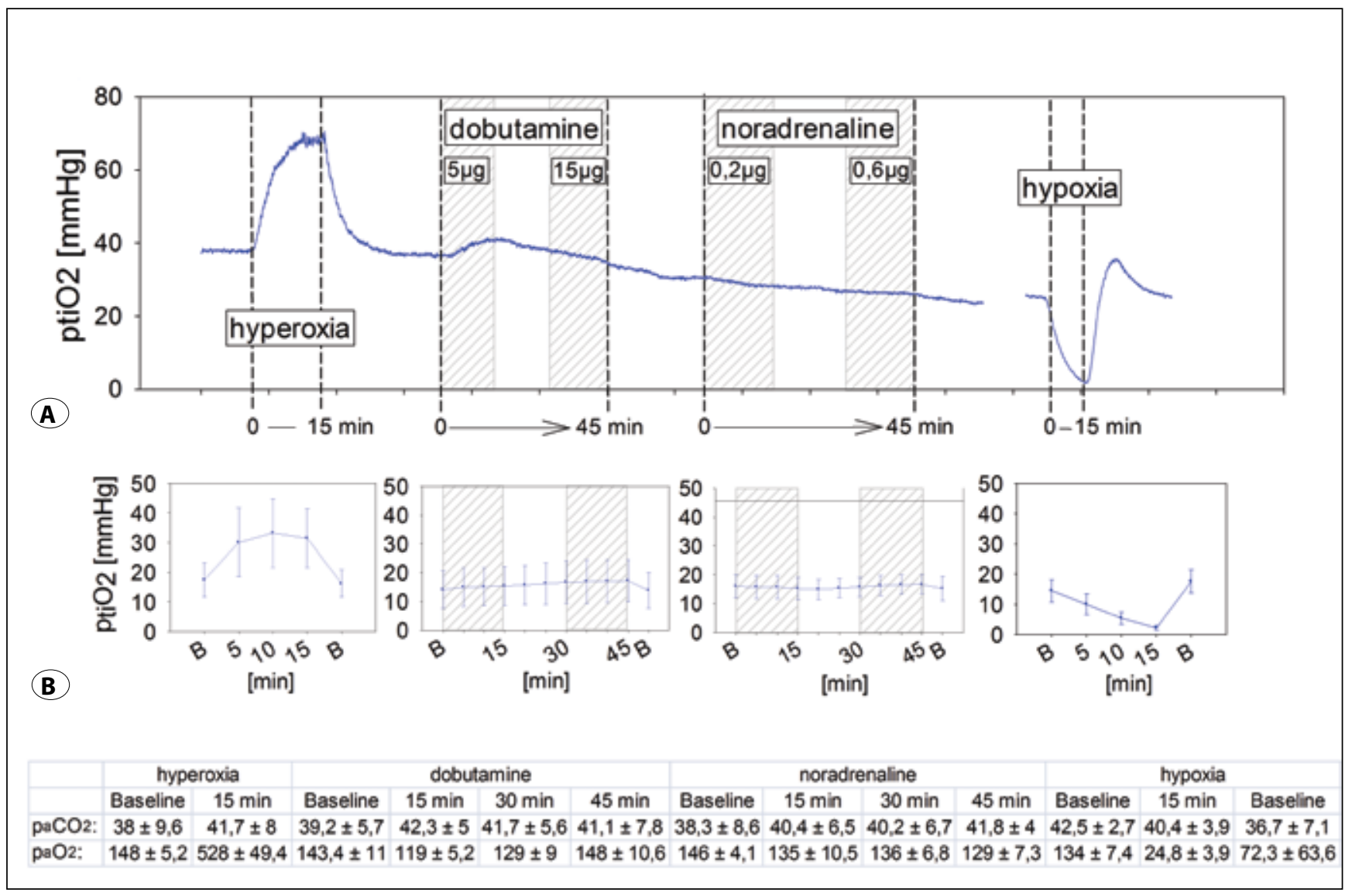

Figure 3: A) Online recording of $\mathrm{ptiO}_{2}[\mathrm{mmHg}]$ during several episodes of the experimental protocol (Figure 2) and $\mathbf{B}$ ) mean value from $12 \mathrm{MPBS}$ in three pigs. $\mathrm{ptiO}_{2}$ values were collected at $1 \mathrm{~Hz}$ and were averaged over $5 \mathrm{~min}$. Arterial blood samples were analysed for $\mathrm{paO}_{2}$ and $\mathrm{paCO}_{2}$ at the beginning (baseline, $\mathrm{B}$ ) and end of each episode which are marked by dashed lines. Pharmacological treatment with dobutamine and peripheral resistance. The expected blood pressure increase by norepinephrine consisted of a step-wise increase of infused concentration (dobutamine: 5,10 and $15 \mu \mathrm{g} / \mathrm{kg} / \mathrm{h}$; norepinephrine $0.2 / 0.4 / 0.6 \mu \mathrm{g} / \mathrm{kg} / \mathrm{h}$ ). Averaged values are given as mean $\pm S D$. *indicate a significant $(p<0.05)$ difference to baseline using a paired t-test. 


\section{Cerebral Blood Flow}

Individual differences of BPU were higher than variability of oxygen or pressure monitoring throughout the experiment. Baseline BPU values ranged from 106 to 2248 BPU. Although mean CBF varied during hyperoxygenation, blood flow remained stable during dobutamine and norepinephrine treatment (Figure 4D). As shown in Figure 4C, treatment with dobutamine did cause a slight increase of CBF. Through the entire protocol CBF changed from 756 \pm 617 BPU (baseline before hyperoxygenation) to $595 \pm 389$ BPU (before hypoxia). Both, the hypercapnic and hypoxic provocation produced changes of CBF that could be detected by the MPBS. On average, elevation was more pronounced during hypercapnia (20\% increase: $582 \pm 329$ to $711 \pm 358 \mathrm{BPU}$ ) than during the hypoxic episode ( $595 \pm 389$ to $606 \pm 378$ BPU). Statistical analysis by paired t-tests of baseline versus the different time-points during each challenge showed that a significant number of Laser-Doppler units picked-up mainly early induced changes (Figure 4D).

The Laser-Dopplers were tested for its 'biological zero' by means of cardiac arrest (KCL injection) in one pig. CBF values dropped to almost zero i.e. $3.2 \%$ of baseline value, within 120 $\mathrm{s}$ of KCL-injection (Figure 5).

\section{Experimental Protocol}

Provocations for MPBS parameters were controlled by blood gas analysis and measurement of hemodynamic parameters (e.g. blood pressure, cardiac output, peripheral resistance). Hyperoxia, hypoxia and hypercapnia caused the intended significant change of $\mathrm{paO}_{2}$ and $\mathrm{paCO}_{2}$, respectively as shown in tables below Figure $3 A, B ; 4 A-D$. Treatment with dobutamine increased cardiac output and reduced peripheral resistance. The expected blood pressure increase by norepinephrine could not be found whereas the highest concentration led to an elevation of heart rate (from $117 \pm 5$ to $134 \pm 18 \mathrm{bpm}$ ) and systolic pressure (from $125 \pm 0.7$ to $141 \pm 7 \mathrm{mmHg}$ ).

\section{DISCUSSION}

An ideal protocol for evaluation of new multi-parametric sensors should include phases during which a particular parameter or a set of parameters is manipulated in a controlled direction. For instance, increased blood $\mathrm{paCO}_{2}$ leads to vasodilation and consequently to elevated blood flow in unharmed tissue. Thus, a hypercapnic episode could be used to evaluate a CBF sensor. A sensor evaluation could be extended further by combining such manipulations with animal models of ischemic or traumatic brain injury with wellknown pathophysiological changes.

Following these principles, Zauner and coworkers tested a multi-parametric probe (Neurotrend, Codman\&Shurtleff, Raynham, USA) that measured oxygen, carbon dioxide, $\mathrm{pH}$ and temperature in a single catheter $(1,42)$. Their experimental protocol consisted of hypo- and hypercapnia by hyperventilation $\left(\mathrm{paCO}_{2}=22 \pm 3 \mathrm{mmHg}\right)$ and hypoventilation $\left(\mathrm{paCO}_{2}=\right.$ $47 \pm 4 \mathrm{mmHg}$ ), ICP increase via intraventricular saline infusion
$( \pm 50 \mathrm{mmHg})$, hypoxemia and finally MCA occlusion in cats. They have been able to evoke the intended changes and to evaluate the new sensor partially by means of an elaborate testing protocol. Despite excellent in vitro performance $(1,13)$, production has been discontinued because the Neurovent probe was instable in long-term measurements in vivo.

Orakcioglu and coworkers compared Licox probes with the new oxygen-temperature sensor Neurovent-TO (Raumedic, Germany) in a porcine model (27). The purpose of their protocol was to evoke various $\mathrm{ptiO}_{2}$ changes through phases of hyperoxygenation ( $\mathrm{FiO}_{2}=1.0$ for 20 minutes), hypotension (verapamil and/or amiodarone; MAP decrease $>40 \mathrm{mmHg}$ for $25 \mathrm{~min}$ ), hypertension (norepinephrine; MAP increase $>40$ $\mathrm{mmHg}$ for $20 \mathrm{~min}$ ) and hyperventilation $\left(\mathrm{paCO}_{2}<25 \mathrm{mmHg}\right.$ for $25 \mathrm{~min})$. Finally, hypoxygenation $\left(\mathrm{FiO}_{2}=0.05\right.$ over 10 minutes) was induced until hypoxic cardiac arrest occurred. Between each maneuver, 10 to 20 minutes were allowed for parameter stabilization. All maneuvers should challenge brain tissue oxygen differently. Using this protocol $\mathrm{ptiO}_{2}$ measured by Neurovent-TO probe (values estimated from line charts) could be increased by about $30 \mathrm{mmHg}$ during $\mathrm{FiO}_{2}=$ 1.0 , by $10 \mathrm{mmHg}$ during hypertension (=CPP increase from 72 to $115 \mathrm{mmHg}$ ) and reduced by $10 \mathrm{mmHg}$ during $\mathrm{FiO}_{2}<$ 0.05 (cardiac arrest). Although CPP decreased significantly during hypotension (78 to $54 \mathrm{mmHg}$ ) mean $\mathrm{ptiO}_{2}$ showed only a $5 \mathrm{mmHg}$ dip. Despite the measurement of ICP for CPP calculation the degree of ICP changes during the maneuvers such as hypoxia were not reported in this study.

Klein et al. ventilated pigs with a $\mathrm{FiO}_{2}$ of 1.0 for 30 min and then induced an episode of apnea by disconnecting the tube until a $\mathrm{SpO}_{2}$, below $50 \%$ was reached (15). This protocol was conducted in order to test the uncoated fluorescence quenching oxygen probe Foxy AL-300 (Ocean Optics) and to compare it to a coated standard probe (Licox). The raised $\mathrm{FiO}_{2}$ and the apnea resulted in $\mathrm{Licox}_{\mathrm{ptiO}_{2}}$ values of $55.2 \pm 29 \mathrm{mmHg}$ and $31.3 \pm 16 \mathrm{mmHg}$, respectively.

Dengler et al. used challenges of hyperoxygenation and hypertension via intravenous titration of norepinephrine to evaluate the Neurovent-PTO (Raumedic, Germany) probe in comatose patients (6). An increase in $\mathrm{FiO}_{2}$ by $20 \%$ for 10 minutes and MAP by $20 \mathrm{mmHg}$ for 10 minutes resulted in a relative incline in $\mathrm{ptiO}_{2}$ by $34.4 \pm 4.6 \%$ and an absolute rise by $3.5 \mathrm{mmHg}$.

A less complex oxygen protocol was used by Morgalla et al. (23) and by Grozinger et al. (10) in order to compare Licox sensors with the new multi-parametric probe Neurovent-PTO (pressure-temperature-oxygen; Raumedic, Germany). They mainly focused on the parameter 'oxygen' of brain tissue but moreover on autoregulatory processes. The used protocol included hepatectomy-induced death and a 10-min oxygen provocation episode $\left(\mathrm{FiO}_{2}=1.0\right)$ at $2 \mathrm{~h}$ after hepatectomy. Pressure or temperature sensors were neither reported nor compared with standard sensors. The oxygen challenge increased $\mathrm{ptiO}_{2}$ up to $100 \mathrm{mmHg}$ and hepatectomy-induced death reduced $\mathrm{ptiO}_{2}$ to almost $0 \mathrm{mmHg}$ (values estimated from Bland-Altman plot). 

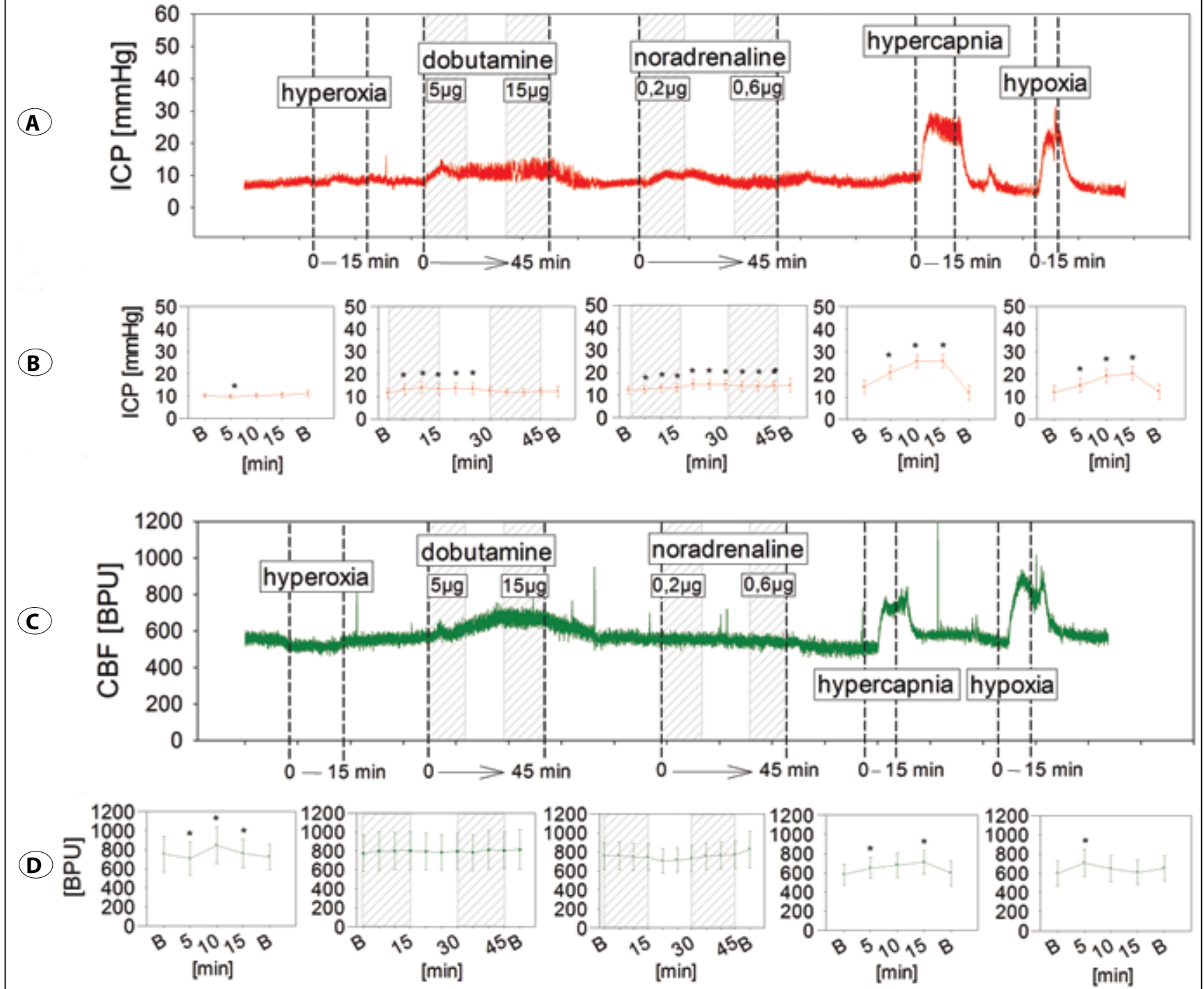

\begin{tabular}{|c|c|c|c|c|c|c|c|c|c|c|}
\hline & \multicolumn{2}{|c|}{ hyperoxia } & \multicolumn{4}{|c|}{ dobutamine } & \multicolumn{4}{|c|}{ noradrenaline } \\
\hline & Baseline & $15 \mathrm{~min}$ & Baseline & $15 \mathrm{~min}$ & $30 \mathrm{~min}$ & $45 \mathrm{~min}$ & Baseline & $15 \mathrm{~min}$ & $30 \mathrm{~min}$ & $45 \mathrm{~min}$ \\
\hline paCO2: & $38 \pm 9,6$ & $41,7 \pm 8$ & $39,2 \pm 5,7$ & $42,3 \pm 5$ & $41,7 \pm 5,6$ & $41,1 \pm 7,8$ & $38,3 \pm 8,6$ & $40,4 \pm 6,5$ & $40,2 \pm 6,7$ & $41,8 \pm 4$ \\
\hline MAP: & $119 \pm 5,7$ & $108 \pm 9,9$ & $108 \pm 12,7$ & $102,5 \pm 3,5$ & $90,7 \pm 8,5$ & $94,7 \pm 2,1$ & $108,5 \pm 7,8$ & $103,7 \pm 12,2$ & $105,7 \pm 7,8$ & $108 \pm 7$ \\
\hline HR: & $95 \pm 17$ & $77 \pm 1,4$ & $83 \pm 1,4$ & $153 \pm 46,7$ & $165,7 \pm 44,6$ & $157,3 \pm 27,1$ & $116,5 \pm 4,9$ & $90,5 \pm 73,1$ & $130,3 \pm 24,4$ & $133,7 \pm 18,1$ \\
\hline $\mathrm{Cl}:$ & $5,6 \pm 2,8$ & 6,9 & 7 & $7,1 \pm 0,4$ & $8 \pm 1,1$ & $8,1 \pm 5,2$ & 7,2 & $7,1 \pm 2,3$ & $7,7 \pm 2,1$ & $7,3 \pm 2,1$ \\
\hline \multirow[t]{3}{*}{ SVRI: } & $1645 \pm 644$ & 1283 & 1370 & $1111 \pm 21,2$ & $1063 \pm 74,2$ & $1149 \pm 632$ & 1182 & $1197 \pm 518$ & $1101 \pm 392$ & $1290 \pm 487$ \\
\hline & \multicolumn{4}{|c|}{ hypercapnia } & \multicolumn{3}{|c|}{ hypoxia } & & & \\
\hline & Baseline & 5 min & $10 \mathrm{~min}$ & $15 \mathrm{~min}$ & Baseline & $15 \mathrm{~min}$ & Baseline & & & \\
\hline paCO2: & $42,5 \pm 2,7$ & $80,1 \pm 1,7$ & $70,5 \pm 39,1$ & $104 \pm 2,6$ & $45,2 \pm 3,2$ & $40,4 \pm 3,9$ & $36,7 \pm 7,1$ & & & \\
\hline MAP: & $98 \pm 12,7$ & 88 & $91 \pm 38,2$ & $93,3 \pm 22,5$ & 111 & $83,3 \pm 39,8$ & $101,5 \pm 10,6$ & & & \\
\hline HR: & $152 \pm 14,1$ & 90 & 165 & $113 \pm 16,4$ & $124,5 \pm 9,2$ & $80,1 \pm 56,9$ & $121,5 \pm 2,1$ & & & \\
\hline $\mathrm{Cl}:$ & 8,1 & 6.2 & 7,1 & $5,6 \pm 2,6$ & 8 & 10.4 & 7.8 & & & \\
\hline SVRI: & 1025 & 1089 & 932 & $1666 \pm 967$ & 1190 & 631 & 1132 & & & \\
\hline
\end{tabular}

Figure 4: Online recording of ICP [mmHg] (A) and CBF [BPU] (C) during episodes of the experimental protocol (Figure 2). Panel B and D show mean value from 12 MPBS in three pigs. ICP and CBF value were collected $1 \mathrm{~Hz}$ and averaged over 5 min. Arterial blood gases $\left(\mathrm{paO}_{2}\right.$ and $\left.\mathrm{paCO}_{2}\right), \mathrm{MAP}, \mathrm{Cl}, \mathrm{SVV}$ and SVI were recorded the beginning (baseline, $\mathrm{B}$ ) and end of each episode which are marked by dashed lines. Pharmacological treatment with dobutamine and norepinephrine consisted of a step-wise increase of infused concentration (dobutamine: 5, 10 and $15 \mu \mathrm{g} / \mathrm{kg} / \mathrm{h}$; norepinephrine $0.2 / 0.4 / 0.6 \mu \mathrm{g} / \mathrm{kg} / \mathrm{h}$ ). Averaged values are given as mean \pm SD. BPU = brain perfusion units, $\mathbf{M A P}=$ mean arterial blood pressure, $\mathbf{S V R I}=$ systemic vascular resistance index; $\mathbf{C l}=\mathbf{c a r d i a c}$ index. ${ }^{*}$ indicate a significant $(p<0.05)$ difference to baseline using a paired t-test. 


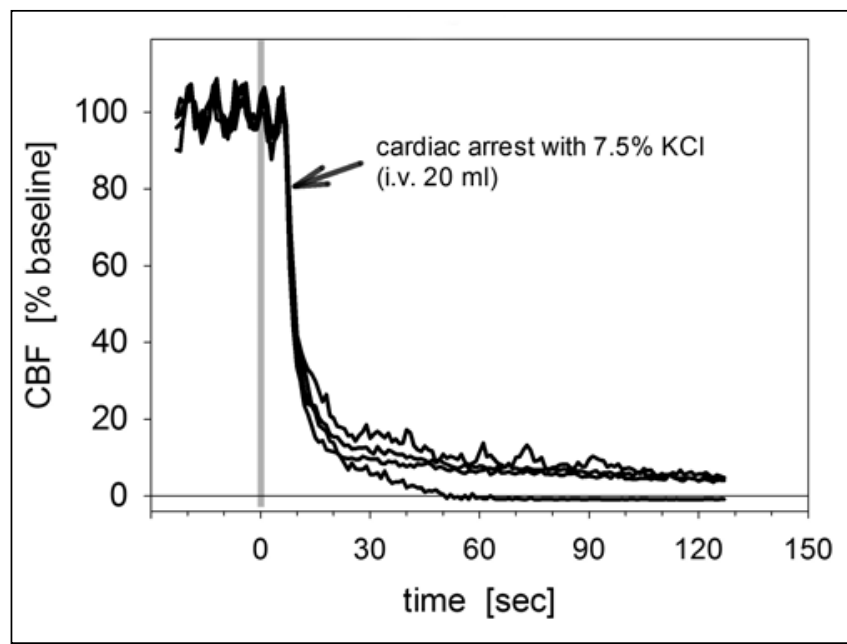

Figure 5: $C B F$ values given as percent baseline for 4 individual MPBS implanted in one pig shortly before and after cardiac arrest by $\mathrm{KCl}$ injection. Mean value of these 4 different MPBS dropped sharply to $3.2 \pm 2.7 \%$ of baseline $(622 \pm 432 \mathrm{BPU}$ to $11.4 \pm 15.0 \mathrm{BPU}$ (individual BPU changes were: 1237 to $-10 ; 607$ to $25 ; 343$ to 16 ; 299 to 15). Brownian motion of molecules and some pendulum flow due to ventilation prevented a decrease to zero. One MPBS had an offset of around 4.5\% (30 BPU) in comparison to the other three MPBS.

These examples show that there seems to be no consensus how new single- or multi-parametric brain sensors should be evaluated in a standardized manner and that challenging factors are poorly reported. A protocol should include not only maneuvers that manipulate measured values in brain tissue, but also upper and lower limits for targeted parameters (e.g. blood pressure, heart rate, arterial $\mathrm{pO}_{2^{\prime}} \mathrm{pCO}_{2^{\prime}}$ ICP). These borders and the actual values should be defined and reported in publications - which is seldomly done.

$\mathrm{ptiO}_{2}$ is often the sole focus in publications despite the use of multi-parametric probes. The measurement of all MPBS parameters - ptiO $(17,25,34,36,39)$, ICP $(8,16,21,26,28,29)$, CBF $(4,5)$ and brain temperature $(33)$ - is considered useful, and can predict and maybe influence outcome. Our goal was to include all those parameters in one test protocol. Therefore, we manipulated brain oxygen by episodes of hyperoxygenation and hypoxia. We demanded an arterial $\mathrm{pO}_{2}$ of $>400 \mathrm{mmHg}$ and $<40 \mathrm{mmHg}$, respectively, in order to standardize our protocol. These $\mathrm{paO}_{2}$ limits have been reached without difficulty in all three pigs by increasing $\mathrm{FiO}_{2}$. This manipulation of $\mathrm{ptiO}_{2}$ via hyperoxic ventilation has similarly been employed in the aforesaid probe evaluations and other studies $(19,20,31,40)$. As shown in Figure $3 A, B$ all MPBS reacted as expected and manipulating $\mathrm{FiO}_{2}$ for sensor evaluation is a valid method.

Ursino et al. (37) showed that the radius of vessels increases until a blood $\mathrm{paCO}_{2}$ of around $70 \mathrm{mmHg}$ in large pial vessels and continues to increase above $70 \mathrm{mmHg}$ in small pial vessels. Therefore we used a $\mathrm{paCO}_{2}$ of $>70 \mathrm{mmHg}$ to standardize the state of hypercapnia as this should cause an increase in CBF by about $50 \%$ (37). Starting from this level there is a good correlation with ICP and MAP in piglet (28). Thus, significant changes of CBF and ICP in brain tissue can be expected. In order to achieve such high $\mathrm{paCO}_{2}$ values we applied the apnoeic oxygenation that resulted in hypercapnia method. Alternatively, blood carbon dioxide could be increased by reducing the respiratory rate (38). This has the disadvantage that high $\mathrm{paCO}_{2}$ levels are difficult to reach without a risk of low oxygenation. Furthermore, a $\mathrm{paCO}_{2}>70 \mathrm{mmHg}$ is hard to reach using this method. For evaluation of $\mathrm{ICP}$ and $\mathrm{CBF}$ of a new multi-parametric probe a more pronounced increase from baseline would be desirable. Other methods to reach higher $\mathrm{paCO}_{2}$ could be the loading of inspired air $/ \mathrm{O}_{2}$ mixture with a predefined concentration of $\mathrm{CO}_{2}(9,14,22)$ or to disconnect mechanical ventilation with simultaneous flooding of lungs with oxygen. The latter method can reliably raise $\mathrm{paCO}_{2}$ over $100 \mathrm{mmHg}$. Since monitoring of inspired air is discontinued, pulsoxymetry on the pig's tail or ear allows an estimation of a sufficient blood oxygen level. Fig 4A/B indicates clearly that ICP can be elevated (from $10 \mathrm{mmHg}$ to $23 \mathrm{mmHg}$ ) using apnoeic oxygenation. There is a positive relationship between $\mathrm{paCO}_{2}$ and ICP due to the attempt to remove $\mathrm{CO}_{2}$ from brain by increasing $\mathrm{CBF}(11,30,41)$. Consequently, a larger blood volume in the brain (CBV) causes ICP to increase under physiological conditions (18). Therefore, apnoeic oxygenation is also a good method to evaluate CBF measurements by MPBS or other probes. Almost $80 \%$ of MPBS showed a relative increase in CBF of more than $10 \%$ due to hypercapnia (Table I, Figure $4 C, D)$. Unexpectedly, two probes picked-up a CBF decrease $(>10 \%)$ during hypercapnia (Table I). The degree of CBF elevation varied between the sensors. The considerable $\mathrm{SD}$ of the CBF values (BPU), which is conditioned by unequal reactions of the respective probes, might be due to both the particular location and depth of the probes within the brain tissue. The measurement of CBF by LDF can be affected by microscopic structures near the probe tip as only a small brain volume is monitored (4). For example, positional variability in blood vessel diameters may influence baseline CBF. Proximity to arterioles might also bias the measured values (14). Thus, local CBF recorded with LDF may not necessarily show good correlation with the real regional $C B F$, though relative changes in perfusion can be detected satisfactorily (7). Hemorrhage and trauma caused by implantation of the MPBS may also have had a distorting effect. This is compounded by our relatively short equilibration time of only $30 \mathrm{~min}$. However, these factor may only partially explain why MPBS did not pick up the expected $50 \%$ CBF change at the reached hypercapnic level.

A hypoxic episode was included to test sensors at low $\mathrm{ptiO}_{2}$ and to cause brain swelling as well as an increased CBF (32). We used a mixture of air/N2 to induce a drop in $\mathrm{paO}_{2}$ but could simultaneously keep $\mathrm{paCO}_{2}$ constant. Thus, an impact of $\mathrm{paCO}_{2}$ on ICP and CBF was excluded. Figure 4C indicates that $C B F$ increased immediately after the start of hypoxia in order to provide more oxygen to the brain tissue. The 
duration of this effect is limited, counteracted by an ICP increase and a drop of CBF follows. The dynamic of CBF, ICP and $\mathrm{ptiO}_{2}$ changes differed between the animals. Whereas a more than $20 \%$ change was found for all $\mathrm{ptiO}_{2}$ and ICP sensors, $56 \%$ of CBF increased and $44 \%$ decreased by more than $10 \%$. Consequently, a hypoxic episode can only be used for parameter comparison with a high rate of data recording and within an individual animal or by using reference probes. Averaging as shown in Figure $3 \mathrm{~B}, 4 \mathrm{~B}$ and $4 \mathrm{D}$ might only be useful if stable inclines or declines of values are achieved by a particular maneuver (e.g. end of hypoxic period). However, the drop of CBF to almost 0 after cardiac arrest (Figure 5) shows the validity of the Laser-Doppler unit of the MPBS sensor.

Our protocol also included an attempt to manipulate cardiac output by dobutamine and blood pressure by norepinephrine. According to the Bayliss effect, CBF is tightly controlled between a mean arterial blood pressure of 50 to $150 \mathrm{mmHg}$ as vascular smooth muscles contract in response to stretch $(2,11,24)$. Increasing cardiac output with a simultaneous decrease of systemic vessel resistance (dobutamine) or an elevated blood pressure (norepinephrine) should only have little effect on $\mathrm{ptiO}_{2^{\prime}} \mathrm{ICP}$ and $\mathrm{CBF}$ as long as blood vessel function is intact and/or autoregulatory limits are not reached. In our tests, dobutamine increased $\mathrm{Cl}$ by $1 \mathrm{l} /$ $\mathrm{min} / \mathrm{m}^{2}$ and decreased SVR by $221 \mathrm{dyn} \times \mathrm{s} / \mathrm{cm}^{5} \mathrm{I}(15 \mathrm{\mu g} / \mathrm{kg} / \mathrm{h}$ after $45 \mathrm{~min}$ ). The application of norepinephrine resulted in a minimal increase in $\mathrm{Cl}$ and a rise in SVR by $108 \mathrm{dyn} \times \mathrm{s} / \mathrm{cm}^{5}$ but failed to elevate mean arterial blood pressure (even at the highest dose of $0.6 \mu \mathrm{g} / \mathrm{kg} / \mathrm{h}$ after $45 \mathrm{~min}$ ). As expected, neither dobutamine nor norepinephrine administration was able to influence $\mathrm{ptiO}_{2}, \mathrm{ICP}$ or CBF considerably and no longterm peaks were observed. Statistical comparison of baseline values with the 3 time-points within challenges indicated, however, that small changes were induced by dobutamine and norepinephrine and could be picked-up the by MPBS (Figure 3B, 4B/D). In order to test the ability of a probe to detect an impaired vascular autoregulation it might be feasible to conduct this protocol also in brain injured animals. This might also accentuate CBF changes induced during hypoxia.

The protocol manipulates $\mathrm{ptiO}_{2}, \mathrm{CBF}$ and ICP reliably and is feasible for evaluation of multi-parametric brain probes like the new MPBS. Most modules of the 12 MPBS reacted as expected during and between the challenges and showed its basic functionality even when combined in a single catheter. Inclusion of challenge repetition might even improve the quality of gathered information. Although most MPBS reacted to challenges as expected the high standard deviation of the 12 sensors indicate that the position of a multi-parametric sensors in the porcine brain influences not only the measured level but also the magnitude of changes.

We propose that this small-scale study protocol should be introduced in pre-clinical evaluation practice as a basis for larger comparative (use of reference probes) and more complex studies (traumatic brain injury, ischemia). This step- by-step evaluation of new sensors will provide an excellent basis for future use of the MPBS in humans.

\section{ACKNOWLEDGEMENT}

We thank A. Ehlert, F. Kafai and M. Malzahn for their technical and secretarial support during the experiments.

\section{DISCLOSURE}

The study is supported by the 'Else Kröner-Fresenius Stiftung' (Homburg, Germany, study A33/2, recipient G. Woebker). Data are part of doctoral thesis of A.H., A.L. and M.M.M. The MPBS catheters were developed in close collaboration of Dr.s A.N. Obeid (Oxford Optronix Ltd., Abingdon, UK) and R. Pauly (Millar Instruments, Houston, TX, USA) with Dr. G. Wöbker.

\section{REFERENCES}

1. Alessandri B, Hoelper BM, Behr R, Kempski O: Accuracy and stability of temperature probes for intracranial application. J Neurosci Methods 139:161-165, 2004

2. Bayliss WM: On the local reactions of the arterial wall to changes of internal pressure. J Physiol 28:220-231, 1902

3. Beynon C, Kiening KL, Orakcioglu B, Unterberg AW, Sakowitz OW: Brain tissue oxygen monitoring and hyperoxic treatment in patients with traumatic brain injury. J Neurotrauma 29:2109-2123, 2012

4. Dagal A, Lam AM: Cerebral blood flow and the injured brain: How should we monitor and manipulate it? Curr Opin Anaesthesiol 24:131-137, 2011

5. De Georgia MA, Deogaonkar A: Multimodal monitoring in the neurological intensive care unit. Neurologist 11:45-54, 2005

6. Dengler J, Frenzel C, Vajkoczy P, Wolf S, Horn P: Cerebral tissue oxygenation measured by two different probes: Challenges and interpretation. Intensive Care Med 37:1809-1815, 2011

7. Dirnagl U, Kaplan B, Jacewicz M, Pulsinelli W: Continuous measurement of cerebral cortical blood flow by laser-Doppler flowmetry in a rat stroke model. J Cereb Blood Flow Metab 9:589-596, 1989

8. Farahvar A, Gerber LM, Chiu YL, Carney N, Hartl R, Ghajar J: Increased mortality in patients with severe traumatic brain injury treated without intracranial pressure monitoring. J Neurosurg 117:729-734, 2012

9. Glass TF, Fabian MJ, Schweitzer JB, Weinberg JA, Proctor KG: The impact of hypercarbia on the evolution of brain injury in a porcine model of traumatic brain injury and systemic hemorrhage. J Neurotrauma 18:57-71, 2001

10. Grozinger $G$, Schenk $M$, Thiel $C$, Thiel $K$, Morgalla $M H$, Schuhmann MU: Is $\mathrm{P}(\mathrm{br}) \mathrm{O}(2)$ pressure reactivity index (ORx) dependent on the type of oxygen probe? An in vivo study. Acta Neurochir Suppl 114:173-176, 2012

11. Hemphill JC 3rd, Knudson MM, Derugin N, Morabito D, Manley GT: Carbon dioxide reactivity and pressure autoregulation of brain tissue oxygen. Neurosurgery 48:377-383; discussion 383-374., 2001

12. Hillered L, Vespa PM, Hovda DA: Translational neurochemical research in acute human brain injury: The current status and potential future for cerebral microdialysis. J Neurotrauma 22:3-41, 2005

13. Hoelper BM, Alessandri B, Heimann A, Behr R, Kempski O: Brain oxygen monitoring: In-vitro accuracy, long-term drift and response-time of Licox- and Neurotrend sensors. Acta Neurochir (Wien) 147:767-774; discussion 774, 2005 
14. Klaessens JH, Kolkman RG, Hopman JC, Hondebrink E, Liem $\mathrm{KD}$, Steenbergen $\mathrm{W}$, de Mul FF, Thijssen JM: Monitoring cerebral perfusion using near-infrared spectroscopy and laser Doppler flowmetry. Physiological Measurement 24: N35-40, 2003

15. Klein KU, Boehme S, Hartmann EK, Szczyrba M, David M, Markstaller K, Engelhard K: A novel technique for monitoring of fast variations in brain oxygen tension using an uncoated fluorescence quenching probe (Foxy AL-300). J Neurosurg Anesthesiol 23:341-346, 2011

16. Lane PL, Skoretz TG, Doig G, Girotti MJ: Intracranial pressure monitoring and outcomes after traumatic brain injury. Can J Surg 43:442-448, 2000

17. Lang EW, Mulvey JM, Mudaliar Y, Dorsch NW: Direct cerebral oxygenation monitoring--a systematic review of recent publications. Neurosurgical review 30:99-106; discussion 106-107, 2007

18. Liem KD, Kollee LA, Hopman JC, De Haan AF, Oeseburg B: The influence of arterial carbon dioxide on cerebral oxygenation and haemodynamics during ECMO in normoxaemic and hypoxaemic piglets. Acta anaesthesiologica Scandinavica Supplementum 107:157-164, 1995

19. Maas Al, Fleckenstein $W$, de Jong DA, van Santbrink $H$ : Monitoring cerebral oxygenation: Experimental studies and preliminary clinical results of continuous monitoring of cerebrospinal fluid and brain tissue oxygen tension. Acta Neurochir Suppl (Wien) 59:50-57, 1993

20. Manley GT, Pitts LH, Morabito D, Doyle CA, Gibson J, Gimbel M, Hopf HW, Knudson MM: Brain tissue oxygenation during hemorrhagic shock, resuscitation, and alterations in ventilation. J Trauma 46:261-267, 1999

21. Menzel M, Rieger A, Roth S, Soukup J, Furka I, Miko I, Molnar P, Peuse C, Hennig C, Radke J: Comparison between continuous brain tissue $\mathrm{pO} 2, \mathrm{pCO} 2, \mathrm{pH}$, and temperature and simultaneous cerebrovenous measurement using a multisensor probe in a porcine intracranial pressure model. $J$ Neurotrauma 15:265-276, 1998

22. Meyer JS, Gotoh F, Akiyama M, Toshitake S: Monitoring cerebral blood flow and oxygen, glucose, lactate and ammonia metabolism. Circulation Research 21:649-660, 1967

23. Morgalla $M H$, Haas $R$, Grozinger $G$, Thiel $C$, Thiel $K$, Schuhmann MU, Schenk M: Experimental comparison of the measurement accuracy of the Licox $((\mathrm{R}))$ and Raumedic $((\mathrm{R}))$ Neurovent-PTO brain tissue oxygen monitors. Acta Neurochir Suppl 114:169-172, 2012

24. Muench $E$, Horn $P$, Bauhuf $C$, Roth $H$, Philipps $M$, Hermann $P$, Quintel M, Schmiedek P, Vajkoczy P: Effects of hypervolemia and hypertension on regional cerebral blood flow, intracranial pressure, and brain tissue oxygenation after subarachnoid hemorrhage. Crit Care Med 35:1844-1851; quiz 1852, 2007

25. Narotam PK, Morrison JF, Nathoo N: Brain tissue oxygen monitoring in traumatic brain injury and major trauma: Outcome analysis of a brain tissue oxygen-directed therapy. J Neurosurg 111:672-682, 2009

26. Nilsson F, Akeson J, Messeter K, Ryding E, Rosen I, Nordstrom $\mathrm{CH}$ :A porcinemodel for evaluation of cerebral haemodynamics and metabolism during increased intracranial pressure. Acta anaesthesiologica. Scandinavica 39:827-834, 1995

27. Orakcioglu B, Sakowitz OW, Neumann JO, Kentar MM, Unterberg A, Kiening KL: Evaluation of a novel brain tissue oxygenation probe in an experimental swine model. Neurosurgery 67:1716-1722; discussion 1722-1713, 2010
28. Paraforou T, Paterakis K, Fountas K, Paraforos G, Chovas A, Tasiou A, Mpakopoulou M, Papadopoulos D, Karavellis A, Komnos A: Cerebral perfusion pressure, microdialysis biochemistry and clinical outcome in patients with traumatic brain injury. BMC research notes 4:540, 2011

29. Raboel PH, Bartek J Jr, Andresen M, Bellander BM, Romner $B$ : Intracranial pressure monitoring: Invasive versus noninvasive methods-A review. Crit Care Res Pract 2012:950393, 2012

30. Reivich M: Arterial Pco2 and Cerebral Hemodynamics. Am J Physiol 206:25-35, 1964

31. Roth S, Menzel M, Rieger A, Soukup J, Furka I, Miko I, Hennig C, Peuse C, Radke J: Continuous pO2 and pCO2 measurement in brain tissue and cerebrovenous blood during different inspired oxygen settings. A porcine model. Acta Chirurgica Hungarica 36:289-291, 1997

32. Seylaz J, Pinard E, Dittmar A, Birer A: Measurement of blood flow, tissue PO2 and tissue PCO2 continuously and simultaneously in the same structure of the brain. Med Biol Eng Comput 17:19-24, 1979

33. Soukup J, Zauner A, Doppenberg EM, Menzel M, Gilman C, Young HF, Bullock R: The importance of brain temperature in patients after severe head injury: Relationship to intracranial pressure, cerebral perfusion pressure, cerebral blood flow, and outcome. J Neurotrauma 19:559-571, 2002

34. Spiotta AM, Stiefel MF, Gracias VH, Garuffe AM, Kofke WA, Maloney-Wilensky E, Troxel AB, Levine JM, Le Roux PD: Brain tissue oxygen-directed management and outcome in patients with severe traumatic brain injury. J Neurosurg 113:571-580, 2010

35. Stewart C, Haitsma I, Zador Z, Hemphill JC 3rd, Morabito D, Manley G 3rd, Rosenthal G: The new Licox combined brain tissue oxygen and brain temperature monitor: Assessment of in vitro accuracy and clinical experience in severe traumatic brain injury. Neurosurgery 63:1159-1164; discussion 11641155,2008

36. Stiefel MF, Spiotta A, Gracias VH, Garuffe AM, Guillamondegui O, Maloney Wilensky E, Bloom S, Grady MS, LeRoux PD: Reduced mortality rate in patients with severe traumatic brain injury treated with brain tissue oxygen monitoring. J Neurosurg 103:805-811, 2005

37. Ursino $\mathrm{M}$, Lodi $\mathrm{CA}$ : Interaction among autoregulation, $\mathrm{CO} 2$ reactivity, and intracranial pressure: A mathematical model. Am J Physiol 274:H1715-1728, 1998

38. Vajkoczy P, Roth H, Horn P, Lucke T, Thome C, Hubner U, Martin GT, Zappletal C, Klar E, Schilling L, Schmiedek P: Continuous monitoring of regional cerebral blood flow: Experimental and clinical validation of a novel thermal diffusion microprobe. $J$ Neurosurg 93:265-274, 2000

39. Valadka $A B$, Gopinath $S P$, Contant $C F$, Uzura M, Robertson CS: Relationship of brain tissue $\mathrm{PO} 2$ to outcome after severe head injury. Crit Care Med 26:1576-1581, 1998

40. van Hulst RA, Haitsma JJ, Klein J, Lachmann B: Oxygen tension under hyperbaric conditions in healthy pig brain. Clinical physiology and functional imaging 23:143-148, 2003

41. van Hulst RA, Hasan D, Lachmann B: Intracranial pressure, brain $\mathrm{PCO} 2, \mathrm{PO} 2$, and $\mathrm{pH}$ during hypo- and hyperventilation at constant mean airway pressure in pigs. Intensive Care Med 28:68-73, 2002

42. Zauner A, Bullock R, Di X, Young HF: Brain oxygen, CO2, pH, and temperature monitoring: Evaluation in the feline brain. Neurosurgery 37:1168-1176; discussion 1176-1167, 1995 